\section{QUALITY PAPER \\ The economic impact of quality management systems in Portuguese certified companies Empirical evidence}

\author{
Paulo Sampaio \\ Systems and Production Department, University of Minho, Braga, Portugal \\ Pedro Saraiva \\ Chemical Engineering Department, University of Coimbra, Coimbra, \\ Portugal, and \\ António Guimarães Rodrigues \\ Systems and Production Department, University of Minho, Braga, Portugal
}

Economic impact in Portuguese companies

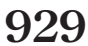

Received July 2010 Revised February 2011 Accepted February 2011

\begin{abstract}
Purpose - Despite all the studies carried out in order to analyze the impact of quality management systems implementation and certification over companies' financial performance, conclusions reached so far have been of a contradictory nature. Some authors conclude that there is a positive relationship between ISO 9001 certification and companies' financial improvement, while others do not find evidence to support such a relationship. Overall, no consistent evidence could therefore be found in the literature concerning the ISO 9001 impact over companies' business financial performance. This work aims to provide a contribution in this area.

Design/methodology/approach - Using a public database of Portuguese companies' financial information, this paper describes the results obtained from studying the economic impact of quality management systems, based on a statistical analysis.

Findings - The results suggest that companies with higher financial performance do present a greater propensity to implement and certify their quality management systems. The ISO 9000 implementation motivation is a critical success factor in the impact of the quality management system over the company economic performance and, for some financial indicators, non-certified companies do present, on average, higher performance than those that are certified.

Originality/value - This paper aims to provide an important contribution to the worldwide research related to the quality management systems impact over companies' financial performance.
\end{abstract}

Keywords ISO 9001 Certification, Economic performance, Quality management, Portugal

Paper type Research paper

\section{Introduction}

A number of studies have been carried out that try to relate the impact of quality management practices over organizational performance. The majority of these studies conclude that there is a positive relationship between the implementation of quality management practices, and organizational performance improvement (Mann and Kehoe, 1994; Maani et al., 1994; Wisner and Eakins, 1994; Adam et al., 1997; Curkovic

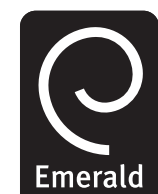

International Journal of Quality \& Reliability Management Vol. 28 No. 9,2011 pp. $929-950$ (C) Emerald Group Publishing Limited 0265-671X 
IJQRM

28,9

930 and Pagell, 1999; Terziovski and Samson, 1999; Gupta, 2000; Romano, 2000; Withers and Ebrahimpour, 2000, 2001; Lee et al., 2001; Singels et al., 2001; Boulter and Bendell, 2002; Dick et al., 2002; Ozgur et al., 2002; Tarí and Molina, 2002; Tarí and Sabater, 2004; Quazi and Jacobs, 2004).

Results obtained by Gupta (2000) show that ISO 9001 certified companies do differ positively from non-certified ones on "technological management", "quality management control", "causes of poor quality" and "quality control techniques used”. Romano (2000) reports statistically significant improvements after ISO 9001 certification, concerning "quality performance in production and on the reliability of the production system" and "external quality performances". He also observed that "non-quality costs" diminished significantly after ISO 9001 certification. Ozgur et al. (2002) point out that the level of usage for the majority of quality tools is higher in ISO 9001 certified firms. Concerning the services sector, Dick et al. (2002) concluded that ISO 9001 certification makes a strong difference in the ways quality is perceived and measured.

Although the majority of the studies carried out state that there is a positive relationship between ISO 9001 certification and performance, as was just mentioned, there is also a group of authors that did not find enough evidence to support such a relationship (Terziovski et al., 1997; Quazi et al., 2002; Conca et al., 2004). Results obtained by Terziovski et al. (1997) showed that the presence or absence of ISO 9001 certification is a poor predictor of organizational performance and quality. Quazi et al. (2002) concluded that there was no statistically significant relationship between ISO 9001 certification status, quality management practices, and quality results.

However, there seems to be a strong relationship between the companies' certification motivations and the corresponding results obtained. When firms simply react to external pressures for getting certified, they may face ISO 9001 registration as a prime objective de per si, adopt a minimalist approach to achieve it, and thus achieve limited internal performance improvements.

Research into the relationship between ISO 90001 certification and the performance of organizations is scarce, and the results seem sometimes contradictory. Further empirical research in this area seems to be necessary. From the academic world, there should be more in-depth analysis of the impact of management models on companies, and more empirical studies from perspectives, which take into account the holistic, and multidimensional reality of companies, should be carried out (Heras and Arana, 2006).

In this paper we present the results obtained from a statistical analysis performed over public financial companies' information (certified and non-certified ones; external motivations and internal ones), in order to analyze the economical impact of the quality management system implementation and certification over companies' performance. We will try to get additional insights to the following research issues:

(1) What is the ISO 9001 economic impact over companies' financial performance?

(2) Are certified organizations more profitable than others?

(3) Is there a relationship between ISO 9001 certification motivations and companies' financial performance?

(4) Are the internal motivations driven companies more profitable than the firms that became certified base on external motivations? 
To achieve these goals, the article proceeds as follows. In the next section we do make a literature review, mainly related to the ISO 9001 certification impact over companies' financial performance. This section is followed by a discussion of methodological issues. The paper proceeds with a presentation of the results obtained. We conclude with a discussion and summary of the implications of this work for research and practice, pointing out also some of our research limitations.

\section{Literature review}

Relationships between ISO 9001 motivations and benefits

ISO 9001 certification motivations can be classified according to one out of two main categories: internal and external motivations. Internal motivations are related with the goal of achieving organizational improvement, while external motivations are mainly related with promotional and marketing issues, customer pressures, improvement of market share, etc.

There is a consensual opinion that ISO 9001 benefits are related with the company certification motivations, i.e. when companies become certified based on internal motivations the derived benefits are fulfilled on a more global dimension. On the other hand, when companies implement ISO 9001 based mostly on external motivations, improvements obtained are then mainly of an external nature (Brown et al., 1998; Gotzamani and Tsiotras, 2002; Corbett et al., 2002; Llopis and Tarí, 2003).

Companies that sought quality certification for "developmental reasons" have experienced more internal benefits from certification. Brown et al. (1998) argued that companies driven by internal reasons to seek certification have a more positive perception about improvements achieved. The manager that sees certification as an opportunity to improve internal processes and systems, rather than simply wanting to get a certificate on the wall, will get broader positive results from ISO 9001 certification. Gotzamani and Tsiotras (2002) stated that companies seeking ISO 9001 certification mainly based on external motivations will also achieve mostly external benefits, while those that seek certification based on true quality improvement will get benefits mainly in terms of internal operations improvement.

Llopis and Tari (2003) suggest that companies more concerned about internal reasons are those that:

(1) Obtain higher profits deriving from the implementation of a quality system.

(2) Reach a greater practical implementation of quality management principles.

(3) Are most likely to progress towards total quality management.

According to the literature, companies maximize their benefits if they achieve ISO 9001 certification based on internal motivations.

ISO 9001 impacts on companies' financial performance

According to Garvin (1984, cited in Sousa and Voss, 2002), the effect of quality over business performance, from a financial perspective, can be based on two main routes: manufacturing and market. In the manufacturing route, improving internal process quality results in better operational performance, which leads to business financial performance. In the market route, improvement of product quality will influence marketing business performance, and from there result in financial performance improvement as well.

\section{Economic impact in Portuguese companies}

931 
IJQRM

28,9

932
According to Sousa and Voss (2002), quality management practices have a significant and strong impact on quality and operational performance. However, their impact over business financial performance is weaker and not always significant. Brust and Gryna (2002) stated the following five economic areas where quality assumes a paramount importance:

(1) Exports competitive advantage.

(2) National trade deficits.

(3) Economic growth.

(4) Productivity and customer satisfaction.

(5) Standardization.

A systematic approach to quality improvement results in two key factors that drive financial performance (George, 2002):

(1) It generates greater value for customers, building market share and revenues.

(2) It lowers costs, increasing margins and asset usage.

Despite all the studies carried out in this area, conclusions reached so far have yet a contradictory nature. Some authors conclude that there is a positive relationship between ISO 9001 certification, and companies' financial improvement (Maani et al., 1994; Wisner and Eakins, 1994; LRQA, 1996; Chapman et al., 1997; Janas and Luczak, 2002; Lee et al., 2001; Beirão and Sarsfield Cabral, 2002; Nicolau and Sellers, 2002; Wayhan et al., 2002; Chow-Chua et al., 2003; Dimara et al., 2004; Naser et al., 2004), while others do not find evidence to support such a relationship (Adam et al., 1997; Kannan et al., 1999; Haversjo, 2000; Lima et al., 2000; Heras et al., 2001, 2002a, b; Aarts and Vos, 2001; Corbett et al., 2002, 2005; Tsekouras et al., 2002; Martínez-Costa and Martínez-Lorente, 2003).

Heras et al. (2001, 2002a, b), regarding better financial performance presented by ISO 9001 certified companies, argued that:

- one must consider the multitude of variables that influence or can influence a company's business financial performance;

- it is important that the characteristics of the samples used are analyzed in greater detail, because it is possible that higher profitability of the certified companies may have to do with the fact that certified firms belong to activity sectors that enjoy greater profitability levels; and

- higher profitability rates verified among ISO 9001 companies may be related with the most profitable companies being those that have a greater propensity to become ISO 9001 certified.

Singels et al. (2001) have not found a positive relationship between ISO certification and performance of organizations. However, the authors have concluded that the motivation for seeking registration has an influence over the organization performance. On the basis of such research results, the authors concluded that ISO 9001 certification based on internal motivations results in improved performance.

Most organizations still seem to pursue ISO 9001 certification based on external pressures, often resulting in a hollow achievement. Only when an organization is 
internally motivated for an improvement of its organizational processes, will certification result in a real significant improvement of its performance.

Terziovski et al. (2003) have found that the quality culture of an ISO 9000 certified organization and the motivation for registration are significant predictors of the value and benefits derived from such a certification. The authors have concluded that the implementation of an ISO 9001 quality management system as part of the continuous improvement company's strategy has a significant impact over organizational performance and conduct to the achievement of higher benefits, than if the quality system is implemented and certified as a reaction to external environmental factors.

Within academia, there are a significant number of research studies, which try to analyze the impact of quality management practices over companies' business results and performance. As is illustrated in Table I, most of the studies carried out were quantitative and based on surveys directed at managers and/or staff responsible for quality control (Heras and Arana, 2006). The authors have stated that those studies are possibly weakened and methodologically distorted by basing themselves only on opinions of company people who had participated in the implementation of the quality systems. As a result of this possible bias, the use of commercial economic and financial databases of information to verify the impact of quality management models on company results has grown in the recent years. Even so, these studies are very limited when establishing causes for the relationships analyzed.

According to Table I, we would like to point out that the majority of ISO 9001 certification research studies conducted in order to analyze the effects of quality management practices over companies' performance are supported by survey methodologies.

Heras and Arana (2006) have used a survey methodology supported by the Delphi method. The authors have concluded that the implementation of quality management models in European companies has a positive influence over company results, mainly through the improvement of operations, efficiency and the costs of companies' internal activities. However, in the opinion of the experts, the direct effect on economic results is not so clear, especially in the case of the ISO 9001 implementation.

As is illustrated in Table I, the use of the case study methodology is scarce. However, one should point out the works carried out by Mo and Chan (1997), Withers and Ebrahimpour (2000), Gustafsson et al. (2001), Merino (2001) and Dwyer (2002), which have used the case study methodology.

Overall, no consistent evidence could therefore be found in the literature concerning the ISO 9001 impact over companies' business financial performance.

Thus, there seems to be room for conducting additional work in order to analyze:

- what is the ISO 9001 certification impact over business financial performance, if any;

- whether "quality organizations" are indeed more profitable and have better "bottom line" results than the others; and

- whether companies that become certified base on internal motivations have different results, also from a financial perspective, as compared to the ones that become certified based mostly on external motivations.

As Heras et al. (2001, 2002a, b) have already stated, one must consider that there is a multitude of variables that could influence a company's business financial performance, and thus it is very important to define a group of variables which
Economic impact in Portuguese companies

933 


\section{IJQRM 28,9}

\section{4}

Romano (2000)

100 Italian companies

Casadesús et al. (2001) Survey mailed to managers 502 companies in Spain

Merino (2001)

1,000 companies in Spain

Tari and Molina (2002) Survey mailed to managers 106 companies in Spain

Gotzamani and Tsiotras (2002)

85 large Greek companies Martinez-Lorente and Martinez-Costa (2002) 442 Spanish companies

Table I.

Principal studies analyzing the effects on results of quality management implementation in Lagrosen and Lagrosen (2005) 266 Swedish organizations
Survey mailed to managers

Survey mailed to managers; case study

Survey mailed to managers Survey mailed to managers and databases Survey of managers and database analysis
Survey mailed to quality professionals
Main conclusions

Certified companies are more profitable than non-certified companies, although certification does not seem to be the cause of the increase in profitability

ISO 9000 certification contributes to improving quality costs, internal and external quality, and production times, although it increases inspection costs

Of the companies 65 per cent obtained improvements, internal as well as external, following implementation of the ISO 9000. The profit-motivation relationship stands out, given that the companies certified for internal reasons obtain greater profits

There are significant sectoral differences between QM practices and their influences on results. The companies reaching the highest indices of QM implementation obtain the best results

The companies in Alicante that have put QM into practice have improved business results, client satisfaction, employee satisfaction and social impact

In the opinion of the managers, ISO 9000 contributes to improving internal company organization and operating results TQM has a positive effect on the operating results. However, the simultaneous application of ISO 9000 and TQM systems cancel those positive effects

The financial results of certified and noncertified companies are analysed, taking into account their strategic orientation, which is, in the end, the variable affecting company profitability (and not the fact of being or not being certified)

The results show that there is a correlation between the adoption of the values of TQM and successful QM. The usefulness of the ISO 9000, Swedish and European Quality Awards, as well as several of the QM tools is also indicated

must reflect the impact of quality management system implementation over company financial performance. It is also important, in order to properly analyze this issue, to reduce the influence of company activity sectors, sizes or other masking factors, because these may also mislead some of the conclusions that one reaches regarding the impact of ISO 9001 certification over financial results. 


\section{Research methodology}

The financial indicators used in our statistical tests were:

- Sales growth (SG).

- Productivity (Prod).

- Operational results over Asset (OR/A).

- Operational results over Sales (OR/S).

We have chosen the previous set of financial indicators because they are available on companies' public financial information and may be influenced by the implementation of quality management systems.

This research was undertaken with companies that operate in Portugal. For that purpose, we have defined two main groups: one is composed by the best Portuguese companies in terms of financial performance, according to a national ranking of such indicators, while the second group is composed by Portuguese ISO 9001 certified small and medium enterprises (SME). The companies used in the first sample were collected from the ranking established by the national magazine Exame for the year 2006 (Exame, 2007), from which we identified a total of 207 top companies in Portugal regarding their "bottom line" results in the corresponding sectors of activity. Out of these, we were able to find out that 143 were ISO 9001 certified, as opposed to the remaining 64 companies. The second set comprises 34 companies, for which the same financial information was available over the Exame ranking, but also were included in a random sample of ISO 9001 certified companies whose audit reports we have examined, and for which we believe to know from previous work (Sampaio et al. 2009, 2010) if external or internal motivations drove their certification. Thus, we were able to find 24 companies with internal motivations and ten companies with external ones, for which financial data were also made available.

\section{Results obtained}

Before presenting the results obtained from statistical tests, we will analyze the companies' financial indicators evolution from 2003 to 2005.

As shown in Figures 1-3, the Exame ranking non-certified companies do present, on average, higher scores than the ISO 9001 certified ones, which comes somewhat as a surprising conclusion. We were also able to verify that those companies that became certified based on internal motivations do present higher scores on the analyzed indicators than the ones that did so based mostly on external motivations.

In this section we will present the results obtained from statistical tests that we have performed over companies' financial indicators. However, before doing so, it is important to summarize some of our main exploratory data analysis results:

- Of the Exame ranking companies, 69 percent were ISO 9001 certified, meaning that financial top performing organizations have a much larger fraction of certifications than the average companies in Portugal.

- Companies in the same ranking that belong to the "Construction", "Electrical and precision equipment", "Chemical" and "Transportation equipment" activity sectors are all ISO 9001 certified.

\section{Economic impact in Portuguese companies}

935 


\section{IJQRM \\ 28,9}

\section{6}

Figure 1.

Productivity evolution (2003-2005)
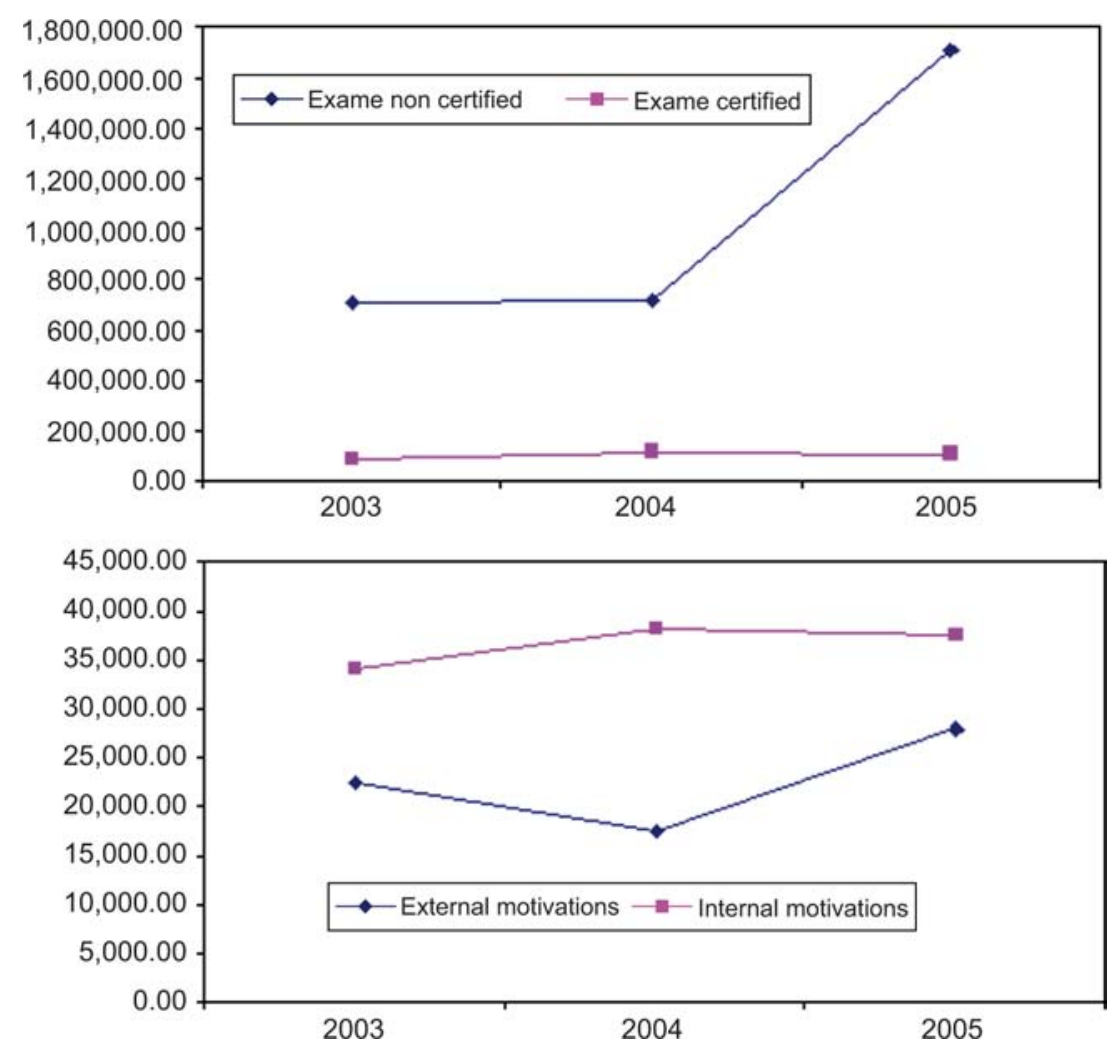

- Of the SME (seven companies), 15 percent belong to the Exame ranking of top financial performance. Six of them have implemented and certified their quality management system based on internal motivations, and only one supported on external ones.

- Of the SME (three companies) 6 percent are the very best Portuguese companies in terms of financial performance in their activity sectors. All of them became certified based on internal motivations.

According to these results, one may point out the following conclusions:

- Those companies that are characterized by having the best financial performances do present higher propensity to implement and certify their quality management systems than average companies. However, as we have already verified, non-certified companies in the top performance ranking seem to present higher scores in the financial indicators analyzed than certified ones.

- The SME that implemented and certified their quality management systems based on internal motivations have higher propensity to become part of the best companies' rankings in Portugal according to financial performance indicators. 

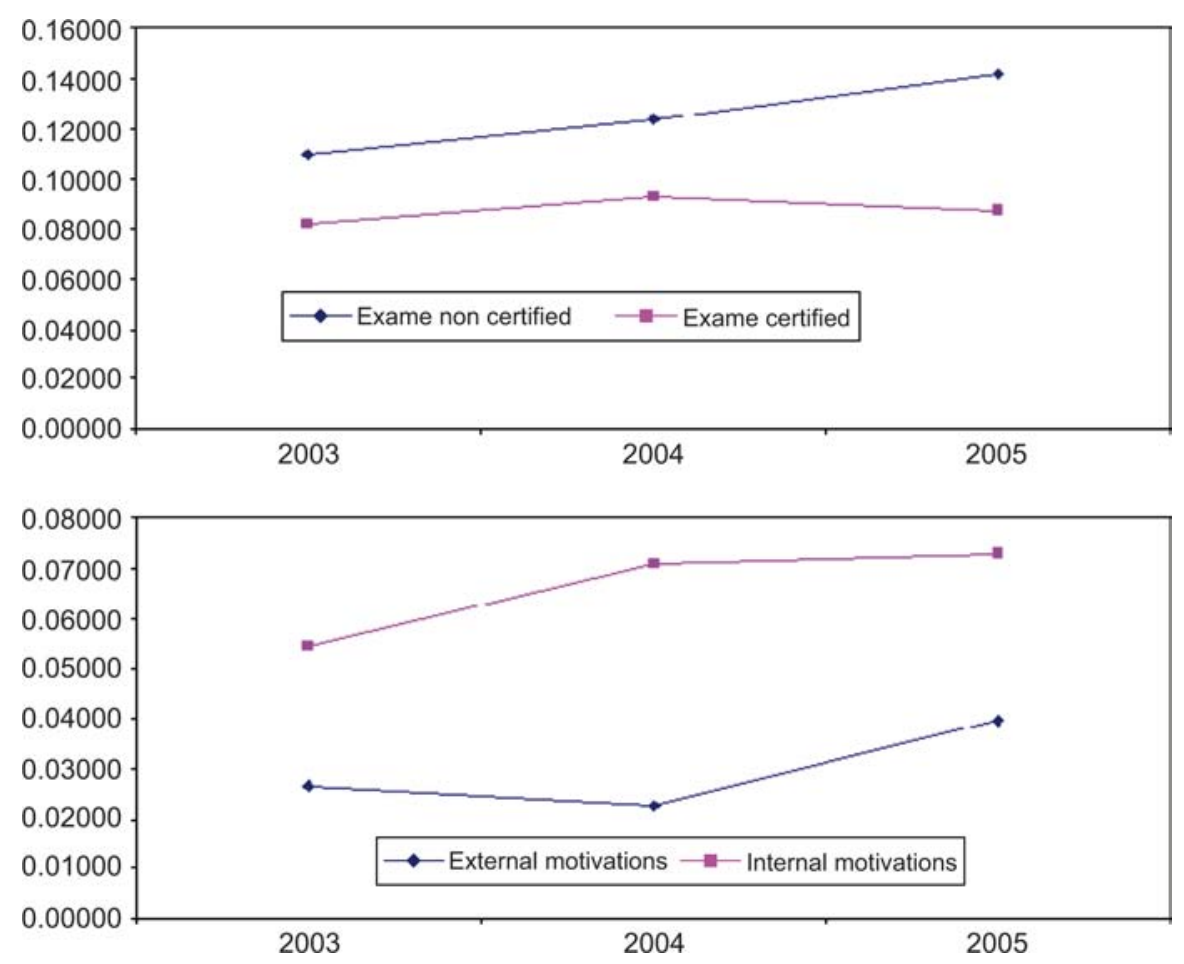

\section{Economic impact in Portuguese companies}

937

Figure 2.

Operational results over Asset evolution (2003-2005)

Regarding the statistical tests, we have used the groups of companies that have already been defined previously. One group is composed by the Exame ranking companies while the other group is composed by the sample of ISO 9001 certified SME that we had previously studied. Thus, we have performed statistical tests in order to compare the following sets of companies:

- Exame ranking non-certified companies (E_NC) versus Exame ranking certified companies (E_C).

- External motivations companies (EM) versus Internal motivations companies (IM).

At first, we performed a univariate statistical analysis, based on the t-test for means comparison (Montgomery and Runger, 1994) and the Wilcoxon-Mann-Whitney (WMW) non-parametric test (Siegel and Castellan, 1988), over the individual financial indicators employed. Then, we also conducted a multivariate test based on the Hotelling mean comparison test (Sharma, 1996; Reis, 1997). We have also used contingency tables (Siegel and Castellan, 1988) with the aim of identifying if the motivation for implementing and certifying a quality management system had any significant impact for the SME belong to the group of companies with best financial performance. 
IJQRM

28,9

938

Figure 3.

Operational results over sales evolution (2003-2005)
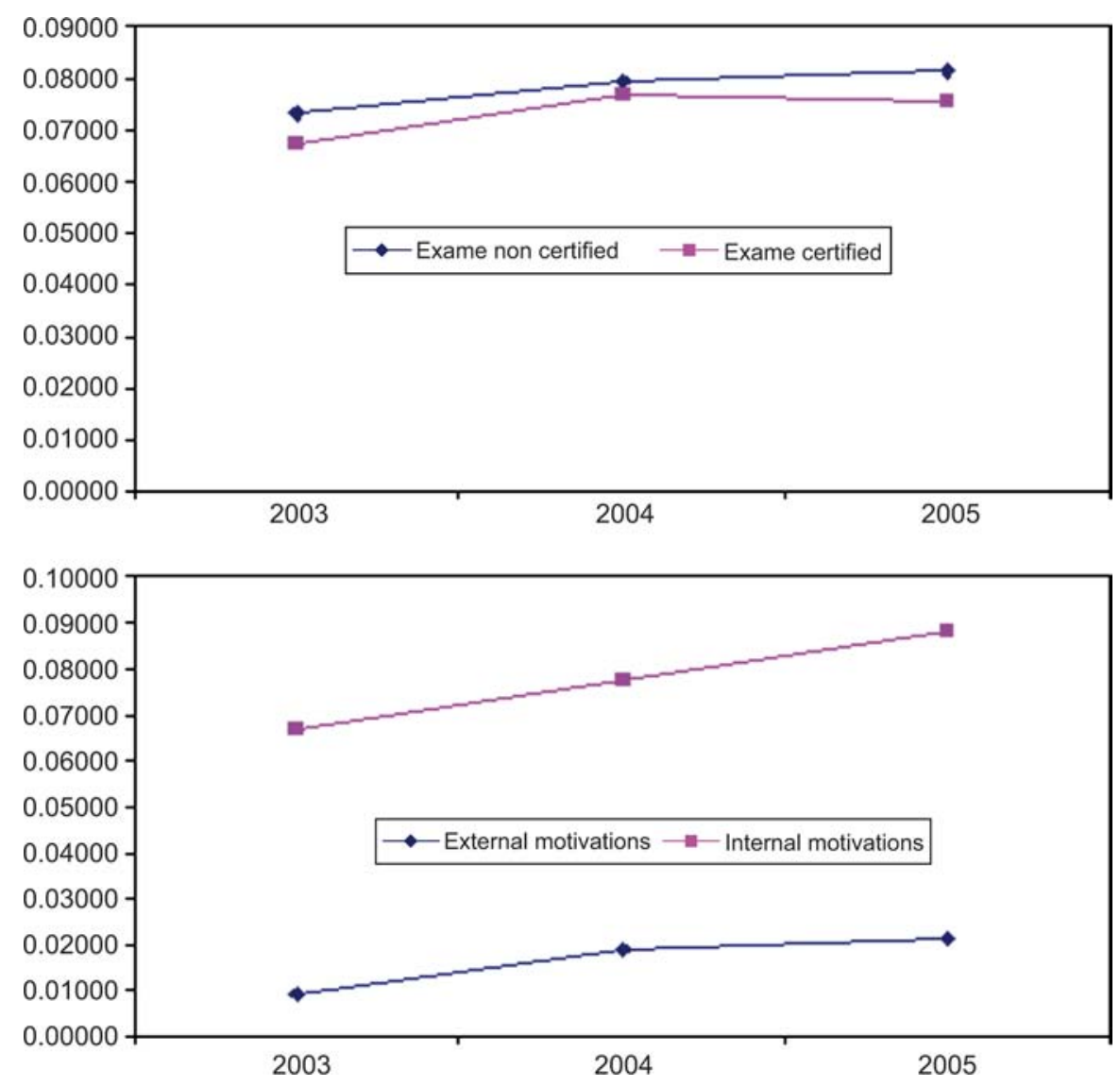

Univariate analysis

Regardless of the differences that have been found in the previous section, between Exame certified and non-certified companies, as illustrated in Table II they are not sustainable at a 0.05 significance level.

Concerning the comparisons between Internal motivations companies and External motivations ones, we have found significant statistical differences for Productivity and for the ratio Operational Results over Sales at a 0.05 significant level (see Table III).

As is illustrated in Figure 4, the internal motivations companies group has higher scores for those financial indicators than the external motivations companies.

Table II.

Comparisons between the

Exame companies

(W-M-W non-parametric

test)

\begin{tabular}{|c|c|c|c|c|}
\hline & \multicolumn{4}{|c|}{ W-M-W test } \\
\hline Companies & SG & Prod & OR/A & $\mathrm{OR} /$ \\
\hline E_NC vs E_C & $\mathrm{N}$ sig & $\mathrm{N}$ sig & $\mathrm{N}$ sig & $\mathrm{Ns}$ \\
\hline$p$-values & 0,143 & 0,140 & 0,078 & 0,9 \\
\hline
\end{tabular}


With aim of verifying if there were significant statistical differences between the ranking positions of the Exame certified and non-certified companies, we have also performed the Wilcoxon-Mann-Whitney non-parametric test, using each company position in its activity sector ranking. Thus, for all of the 207 companies, we have identified which was their position in the respective activity sector ranking, and then used it to perform positions comparisons.

According to Table IV, we were able to find out that there are no significant statistical differences between the two groups of companies, in terms of their activity sectors ranking positions. Thus, we can conclude that ISO 9001 certification does not influence the company position in the ranking of the best companies of its activity sector concerning the financial performance.

Based on a contingency table and the Fisher's Exact test, we have also analyzed if those SME that became ISO 9001 certified based mainly on internal motivations have higher propensity to belong to the ranking of the companies with the best financial performance. According the results obtained, we can conclude that the ISO 9001 motivation is not a significant variable for a company to belong to the ranking of the best companies in their activity sectors $\left(\chi^{2}=1,209\right.$, d.f. $=1, p$-value $\left.>0,05\right)$.

According to Table $\mathrm{V}$, we have found significant statistical differences between the Exame certified and non-certified companies for the indicator Operational Results over Asset at a 0,05 significance level. It is important to point out that this statistical difference was not found when we have used a non-parametric test. However, the $p$-value for the non-parametric test was of 0,078 , and therefore close to 0,05 . As is illustrated in Table $\mathrm{V}$, and according to the $p$-value related to the Levene test, there was only equal variance for the ratio Operational Results over Sales.

Non-certified companies do present, on average, higher Operational Results over Asset scores than ISO 9001 certified ones. As is illustrated in Figure 5, one must however point out that the presence of outliers in both groups of companies can be the cause of the significant statistical difference obtained here under a parametric test.

According to Heras et al. (2001, 2002a, b), regarding better financial performance presented by ISO 9001 certified companies, the authors argued that one must consider that it is possible that higher profitability of the certified companies may have to do with the fact that certified firms belong to activity sectors that enjoy greater profitability levels. In order to avoid that possible bias, we have also standardized the financial indicator values, according to the sector averages. Thus, for each activity sector ranking, and for each company, we have computed a standardized value of each financial indicator from its sector mean value and standard error. The corresponding standardized values were computed according to:

\begin{tabular}{lcccc}
\hline Companies & SG & $\begin{array}{c}\text { Prod } \\
\text { Sig }\end{array}$ & $\begin{array}{c}\text { OR/A } / \text { test } \\
\text { N sig }\end{array}$ & OR/S \\
EM IM & N sig & 0,031 & 0,148 & 0,016
\end{tabular}

Economic impact in Portuguese companies

939

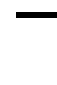


IJQRM

28,9

940

Figure 4.

Productivity and operational results over sales confidence intervals (external and internal motivations companies)
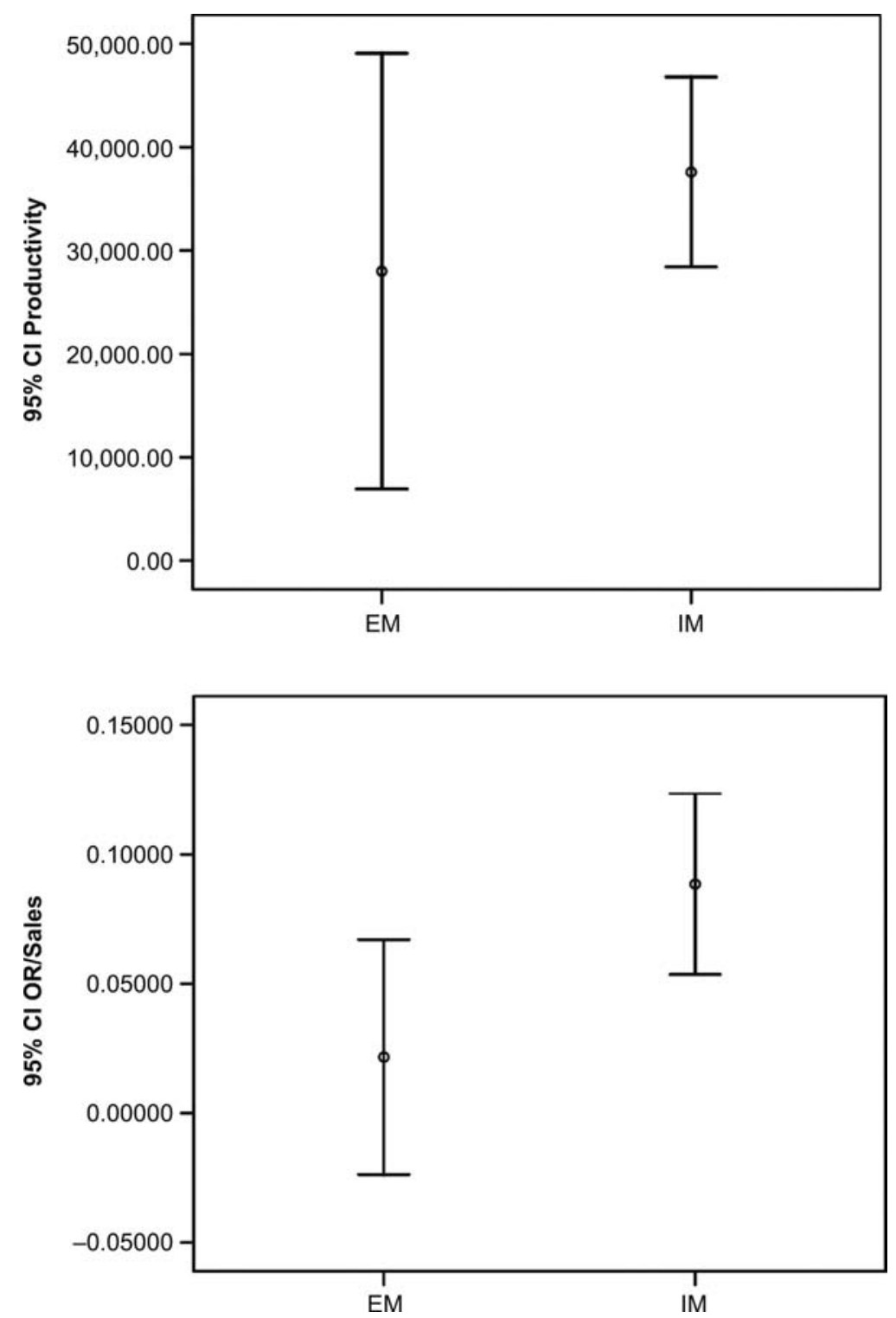

Table IV.

Comparisons between

Exame companies activity sector ranking (W-M-W non-parametric test)
Companies

E_NC vs E_C

$p$-value
W-M-W test N sig

0,317 


$$
z_{k, j, i}=\frac{x_{k, j, i}-\mu_{k, i}}{\sigma_{k, i}}
$$

where:

$z_{k, j, i}$ - standardized value for financial indicator $k$ and company $j$, for activity sector $i$.

$x_{k, j, i}-$ absolute value for financial indicator $k$, company $j$, and activity sector $i$.

$\mu_{k, i}-$ mean value for financial indicator $k$, in activity sector $i$.

$\sigma_{k, i}-$ standard error for financial indicator $k$, in activity sector $i$.

Regarding the results obtained with a non-parametric test, we have found significant statistical differences between the Exame ISO 9001 certified companies and non-certified firms for the Sales growth indicator, whose $p$-values can be found in Table VI.

According to Table VII, based on a parametric test we had not found any statistical differences between the two previous groups of companies. However, as is illustrated in Figure 6, the presence of outliers can influence such a result.

Concerning our data statistical univariate analysis, some main results can be summarized as follows:

- We have found significant statistical differences between the SME certified based on internal motivations and those that became certified mostly because of external issues, regarding Productivity and Operational Results over Sales. The internal motivations companies do present, on average, higher scores for the previous financial indicators than the external motivations firms.

- We have found significant statistical differences between the Exame ranking non-certified companies and the certified ones for the following financial indicators: Sales growth and Operational results over Asset.

\section{Multivariate analysis}

A multivariate analysis was performed only for the Exame ranking companies, because this data set was found to be the only one meeting most of the needed underlying assumptions (Sharma, 1996):

- Multivariate normal distribution.

- Covariance matrices for all the groups are equal.

- Observations are independent.

\begin{tabular}{|c|c|c|c|c|c|}
\hline & & & & & \\
\hline & SG & Prod & OR/A & OR/S & \\
\hline Levene test & 0,003 & 0,000 & 0,000 & 0,695 & \\
\hline$T$ & 1,030 & 1,240 & 2,748 & 0,376 & Table V. \\
\hline$p$-values & 0,307 & 0,220 & 0,007 & 0,707 & Comparisons between \\
\hline E_NC vs E_C & $\mathrm{N}$ sig & $\mathrm{N}$ sig & Sig & $\mathrm{N}$ sig & Exame companies ( $t$-test) \\
\hline
\end{tabular}

\section{Economic impact in Portuguese companies}

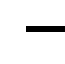


IJQRM

28,9

\section{2}

Figure 5.

Operational results over Asset variable observations distribution (Exame companies)
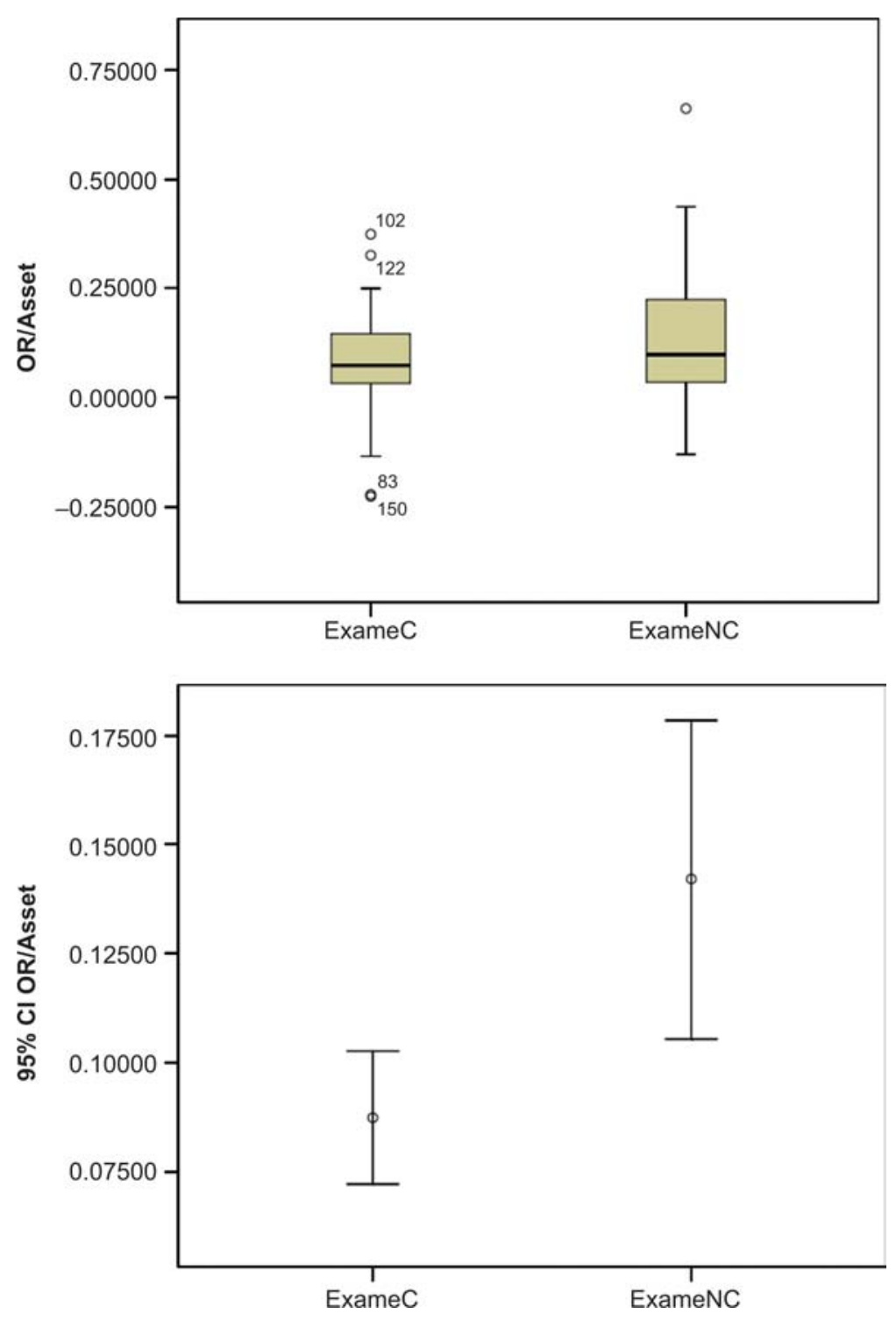

Table VI.

Comparisons between the Exame companies standardize values (W-M-W non-parametric test)

\begin{tabular}{lcccc}
\hline & & \multicolumn{2}{c}{ W-M-W test } & \\
Companies & SG & Prod & OR/A & OR/S \\
E_NC vs E_C & Sig & N sig & N sig & N sig \\
\hline$p$-values & 0,024 & 0,631 & 0,343 & 0,812 \\
\hline
\end{tabular}


This analysis was performed both for the financial indicators on absolute values and over the corresponding standardized values.

As is illustrated in Table VIII, the Box's M statistic is significant, indicating that the covariance matrices are not equal. In spite of this violation of the previous assumptions, we found significant statistical differences between the Exame ISO 9001 certified and non-certified companies for the group of financial indicators analyzed (see Table IX).

According to Table $\mathrm{X}$, the violation of the equality of covariance matrices is certainly being caused by the unequal variance found for the variables Sales growth, Productivity and Operational Results over Asset.

As is illustrated in Table XI, the Box's M statistic is still significant at a 0,05 significance level, allowing one to conclude that there is no equality of the covariance matrices for the standardized values. However, according to Table XII we were able to find out that using the standardized values there were no significant statistical differences between the certified and non-certified companies.

According to Table XIII, one can verify that there is no equal variance for the variable Operational Results over Asset. Once again, this could be one of the causes of the unequal covariance matrices.

\section{Conclusions}

The research presented here had the aim of analyzing the economical impact of the quality management system implementation and certification over companies' performance. In this paper we have presented the results obtained with a statistical analysis supported in univariate and multivariate tests, which we have performed over public financial companies' information (certified and non-certified ones; external motivations and internal ones).

Before evaluating the quality management system impact over companies' financial performance it is important to analyze the company main ISO 9001 certification motivations. There is a consensual opinion that ISO 9001 benefits are related with the company certification motivations, i.e. when companies become certified based on internal motivations the derived benefits are fulfilled on a more global dimension. On the other hand, when companies implement ISO 9001 based mostly on external motivations, improvements obtained are mainly of an external nature. Internal motivations companies do present higher benefits perceptions (mainly in terms of internal organization), but the companies that became certified based mainly on external motivations can more easily quantify the economic benefits that have resulted from their quality management system implementation.

Based on the statistical analysis that was performed, we can point out the following main results:

\begin{tabular}{|c|c|c|c|c|c|}
\hline & \multicolumn{4}{|c|}{$t$-test } & \multirow{6}{*}{$\begin{array}{r}\text { Table VII. } \\
\text { Comparisons between the } \\
\text { Exame companies - } \\
\text { standardized values } \\
(t \text {-test) }\end{array}$} \\
\hline & SG & Prod & $\mathrm{OR} / \mathrm{A}$ & OR/S & \\
\hline Levene test & 0,723 & 0,104 & 0,014 & 0,616 & \\
\hline & 1,844 & 0,863 & 1,666 & 0,464 & \\
\hline$p$-values & 0,067 & 0,389 & 0,099 & 0,643 & \\
\hline E_NC vs E_C & $\mathrm{N}$ sig & $\mathrm{N}$ sig & $\mathrm{N}$ sig & $\mathrm{N}$ sig & \\
\hline
\end{tabular}

in Portuguese companies

943 
IJQRM

28,9

\section{4}

Figure 6.

Sales growth variable observations distribution (Exame companies)
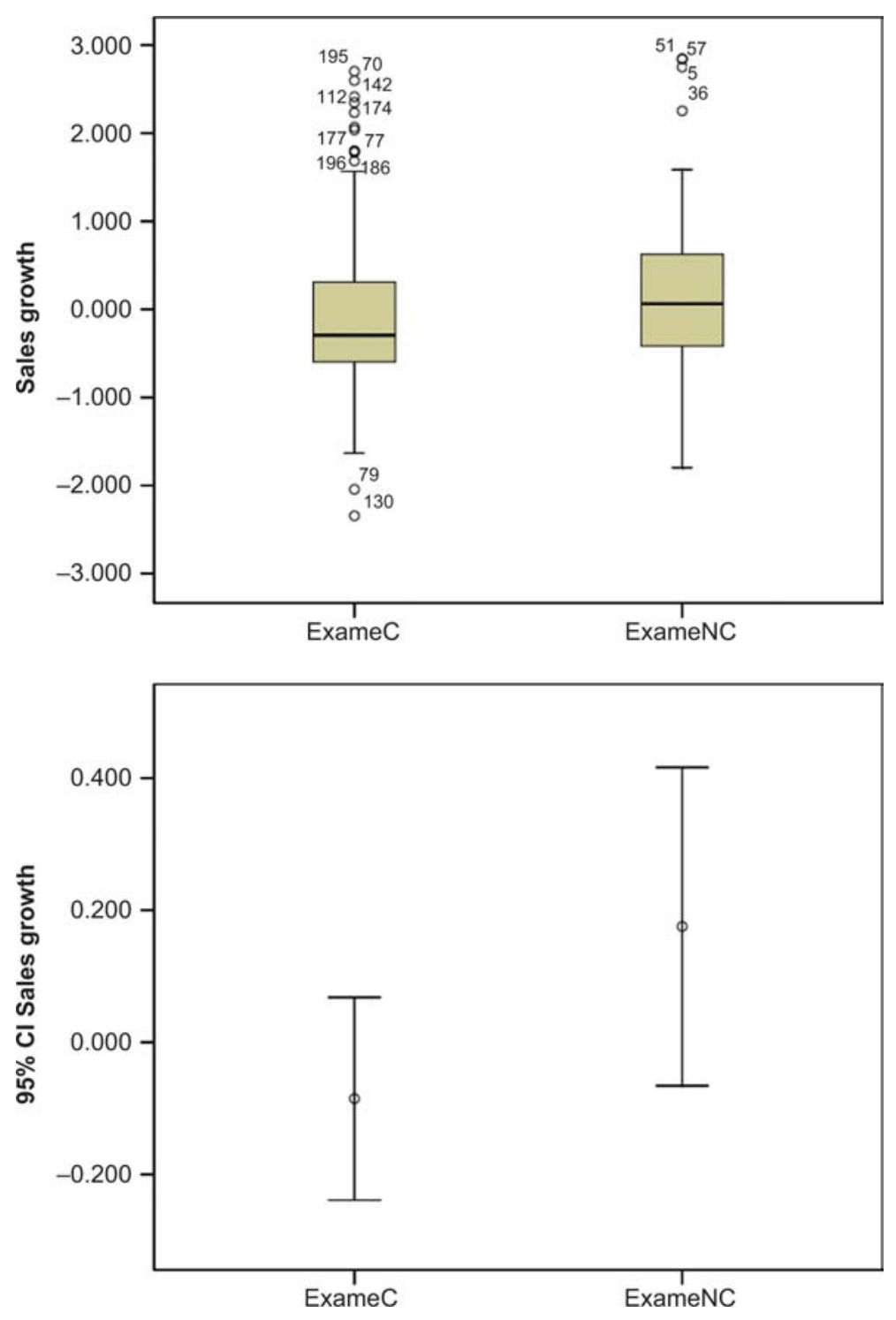

Table VIII.

Covariance matrices homogeneity test
Box's M

F

$p$-value
2034,966

198,192

0,000

Sig 
- The best Portuguese companies in terms of financial performance do present greater propensity to implement and certify their quality management systems than the average companies.

- Significant statistical differences, at a significance level of 0,05 , between the group of companies that became certified based on Internal Motivations and those certified based on External Motivations, were found for the following indicators: Productivity and ratio Operational Results over Sales. The internal motivations companies do present on average higher performances than the external motivations ones.

- For the group of best Portuguese companies in terms of financial performance, we found significant statistical differences, at a 0,05 significance level, between the certified and non-certified companies for the following indicators: Sales growth and ratio Operational Results over Asset. The non-certified companies do present on average higher performance than the certified ones.

Our research has however several limitations. First-of-all, our research scope is limited to the Portuguese ISO 9000 certified companies. Nevertheless, by including a considerable number of internationally based corporations, operating in Portugal, our

\begin{tabular}{|c|c|c|c|c|}
\hline \multirow[t]{2}{*}{ Hotelling's Trace } & \multicolumn{2}{|r|}{ Value } & $F$ & $p$-value \\
\hline & & 0,096 & 4,821 & 0,001 \\
\hline & \multicolumn{2}{|l|}{ SG } & Prod & $\mathrm{OR} / \mathrm{A}$ \\
\hline$F$ & \multicolumn{2}{|l|}{8,954} & 12,961 & 17,114 \\
\hline \multirow[t]{2}{*}{$p$-value } & \multirow{2}{*}{\multicolumn{2}{|c|}{$\begin{array}{c}0,003 \\
\text { Sig }\end{array}$}} & \multirow{2}{*}{$\begin{array}{l}0,000 \\
\text { Sig }\end{array}$} & 0,000 \\
\hline & & & & Sig \\
\hline
\end{tabular}

Box's M

F

$p$-value
26,863

2,616

0,004

Sig
Economic impact in Portuguese companies

945
Table IX.

Hotelling test results

\begin{tabular}{ccccc}
\hline Hotelling's Trace & Value & $F$ & $p$-value & \\
\hline 0,037 & 1,831 & 0,124 & $\mathrm{~N}$ si
\end{tabular}

Table XII.

Hotelling test results (standardized values)

\begin{tabular}{lcccc}
\hline & SG & Prod & OR/A & OR/S \\
\hline$F$ & 0,108 & 2,587 & 6,193 & 0,253 \\
$p$-value & 0,743 & 0,109 & 0,014 & 0,616 \\
& N sig & N sig & Sig & N sig
\end{tabular}

Table XIII.

Levene test results (standardized values) 
IJQRM

28,9

946 findings may be also valid in other countries. Another limitation is that the research did not consider other quality programs or initiatives that might be implemented by the companies, especially by non-ISO 9001 certified companies. Although ISO 9001 certified firms seem to be more quality oriented than non-ISO 9001 certified firms, it was not possible to determine if these companies used any other quality programs.

The research presented here has some implications both for academicians and practitioners. For the academic community, this work constitutes an effort to provide an important contribution for studying the ISO 9000 impact over companies' economic performance. For practitioners, particularly ISO 9000 certified companies, this research shows some clues concerning the relationship between ISO 9000 certification and companies' financial performance, in particular regarding how certification motivations can be an important issue for the performance improvement and which financial indicators could be used to reflect the quality management system impact over organizational performance.

Based on the literature review that supported our research and in our findings, we would like to enumerate the following set of specific research questions that will deserve further attention in the future:

(1) Is it possible to reconstruct the economic-financial companies' history of a company, with the aim of identifying the benefits and costs directly related to their quality management systems implementation and certification?

(2) Are ISO 9001 certified organizations more profitable than similar non-certified organizations?

(3) Is there any causal relationship between ISO 9000 certification and companies economic performance?

Given the economic and social relevance of the ISO 9000 phenomenon, as well as the increasing availability of data related to it, we feel that more and more fact-based and statistically oriented studies should be conducted in this area. Regardless of the panoply of research projects conducted so far, in order to analyze the quality management systems impact over companies' financial performance, the results reached here are of a contradictory nature. Based on our findings, this issue is far from being answered, and mixed results were obtained. We have seen that the majority of ISO 9001 certified companies is not able to support the fact that quality management system implementation does have a positive impact over companies' financial performance. Furthermore, it is not possible to state, from our data, that ISO 9001 certification does lead to better financial performance, but it appears to be the case that internal motivation driven certification is more likely to provide increased financial performance than external motivation driven certification.

\section{References}

Aarts, F. and Vos, E. (2001), “The impact of ISO registration in New Zealand firms' performance: a financial perspective", The TQM Magazine, Vol. 13 No. 3, pp. 180-91.

Adam, E. Jr, Corbett, L., Flores, B., Harrison, N., Lee, T., Rho, B., Ribera, J., Samson, D. and Westbrook, R. (1997), "An international study of quality improvement approach and firm performance”, International Journal of Quality \& Reliability Management, Vol. 17 No. 9, pp. 842-73. 
Beirão, G. and Sarsfield Cabral, J. (2002), "The reaction of the Portuguese stock market to ISO 9000 certification”, Total Quality Management, Vol. 13 No. 4, pp. 465-74.

Boulter, L. and Bendell, T. (2002), "How can ISO 9000:2000 help companies achieve excellence?”, Measuring Business Excellence, Vol. 6 No. 2, pp. 37-41.

Brust, P. and Gryna, F. (2002), "Quality and economics: five key issues", Quality Progress, October, pp. 64-9.

Casadesús, M., Giménez, G. and Heras, I. (2001), "Benefits of ISO 9000 implementation in Spanish industry", European Business Review, Vol. 13 No. 6, pp. 327-35.

Chapman, R., Murray, P. and Mellor, R. (1997), "Strategic quality management and financial performance indicators", International Journal of Quality \& Reliability Management, Vol. 14 No. 4, pp. 432-48.

Chow-Chua, C., Goh, M. and Boon Wan, T. (2003), "Does ISO 9000 certification improve business performance?”, International Journal of Quality \& Reliability Management, Vol. 20 No. 8, pp. 936-53.

Conca, F., Llopis, F. and Tarí, J. (2004), "Development of a measure to assess quality management in certified firms", European Journal of Operational Research, Vol. 156, pp. 683-97.

Corbett, C., Montes-Sancho, M. and Kirsch, D. (2005), "The financial impact of ISO 9000 certification in the US: an empirical analysis", Management Science, Vol. 51 No. 7, pp. 1046-59.

Corbett, C., Montes, M., Kirsch, D. and Alvarez-Gil, M. (2002), “Does ISO 9000 certification pay?”, ISO Management Systems, July-August.

Curkovic, S. and Pagell, M. (1999), "A critical examination of the ability of ISO 9000 certification to lead to a competitive advantage", Journal of Quality Management, Vol. 4 No. 1, pp. 51-67.

Dick, G., Gallimore, K. and Brown, J. (2002), "Does ISO 9000 accreditation make a profound difference to the way service quality is perceived and measured?", Managing Service Quality, Vol. 12 No. 1, pp. 30-42.

Dimara, E., Sakuras, D., Tsekouras, K. and Goutsos, S. (2004), "Strategic orientation and financial performance of firms implementing ISO 9000”, International Journal of Quality \& Reliability Management, Vol. 21 No. 1, pp. 72-89.

Dwyer, G. (2002), "Business excellence versus ISO 9000 in an Irish context - which delivers?", Managerial Auditing Journal, Vol. 17 No. 7, pp. 404-11.

Exame (2007), Exame 500 Maiores \& Melhores - Edição 2006, Edimpresa, Lisbon.

George, S. (2002), “Bull or bear?”, Quality Progress, April, pp. 32-7.

Gotzamani, K. and Tsiotras, G. (2002), "The true motives behind ISO 9000 certification: their effect on the overall certification benefits and long-term contribution towards TQM", International Journal of Quality \& Reliability Management, Vol. 19 No. 2, pp. 151-69.

Gupta, A. (2000), "Quality management practices of ISO vs non-ISO companies: a case of Indian industry”, Industrial Management \& Data Systems, Vol. 100 No. 9, pp. 451-5.

Gustafsson, R., Klefsjo, B., Berggren, E. and Granfors-Wellemets, U. (2001), "Experiences from implementing ISO 9000 in small enterprises - a study of Swedish organizations", The TQM Magazine, Vol. 13 No. 4, pp. 232-46.

Haversjo, T. (2000), "The financial effects of ISO 9000 registration for Danish companies", Managerial Auditing Journal, Vol. 15 No. 1, pp. 47-52.

Heras, I. and Arana, G. (2006), “The impact of quality management in European companies' performance", European Business Review, Vol. 18 No. 2, pp. 114-31.

\section{Economic impact in Portuguese companies}


IJQRM

28,9

948
Heras, I., Casadésus, M. and Dick, G. (2002a), "ISO 9000 certification and the bottom line: a comparative study of the profitability of Basque region companies", Managerial Auditing Journal, Vol. 17 No. 1, pp. 72-8.

Heras, I., Casadésus, M. and Ochoa, C. (2001), "Effects of ISO 9000 certification on companies' profitability: an empirical study", Proceedings of the 6th International Conference on ISO 9000 and TQM, Ayr.

Heras, I., Dick, G. and Casadésus, M. (2002b), "ISO 9000 registration's impact on sales and profitability: a longitudinal analysis of performance before and after accreditation", International Journal of Quality \& Reliability Management, Vol. 19 No. 6, pp. 774-91.

Janas, I. and Luczak, H. (2002), "Explorative study of the expected consequences for existing quality management systems due to the revision of ISO 9001 in certified companies in Germany", The TQM Magazine, Vol. 14 No. 2, pp. 127-32.

Kannan, V., Tan, K., Handfield, R. and Ghosh, S. (1999), "Tools and techniques of quality management: an empirical investigation of their impact on performance", Quality Management Journal, Vol. 6 No. 3, pp. 34-49.

Lagrosen, Y. and Lagrosen, S. (2005), "The effects of quality management - a survey of Swedish quality professionals", International Journal of Operations \& Production Management, Vol. 25 No. 10, pp. 940-52.

Lee, C., Lee, T. and Chang, C. (2001), "Quality/productivity practices and company performance in China”, International Journal of Quality \& Reliability Management, Vol. 18 No. 6, pp. 604-25.

Lima, M., Resende, M. and Hasenclever, L. (2000), "Quality certification and performance of Brazilian firms: an empirical study", International Journal of Production Economics, Vol. 66, pp. 143-7.

LRQA (1996), Fitter Finance: the Effects of ISO 9000 on Business Performance, Lloyd's Register Quality Assurance.

Maani, K., Putterill, M. and Sluti, D. (1994), "Empirical analysis of quality improvement in manufacturing", International Journal of Quality \& Reliability Management, Vol. 11 No. 7, pp. 19-37.

Mann, R. and Kehoe, D. (1994), "An evaluation of the effects of quality improvement activities on business performance", International Journal of Quality \& Reliability Management, Vol. 11 No. 4, pp. 29-44.

Martínez-Costa, M. and Martínez-Lorente, A. (2003), "Effects of ISO 9000 certification on firms' performance: a vision from the market”, TQM \& Business Excellence, Vol. 14 No. 10, pp. 1179-91.

Merino, J. (2001), La calidad en la empresa española, Fundación BBV, Bilbao.

Mo, J. and Chan, A. (1997), "Strategic for the successful implementation of ISO 9000 in small and medium manufacturers”, The TQM Magazine, Vol. 9 No. 2, pp. 135-45.

Montgomery, D. and Runger, G. (1994), Applied Statistics and Probability for Engineers, John Wiley \& Sons, New York, NY.

Naser, K., Karbhari, Y. and Mokhtar, M. (2004), "Impact of ISO 9000 registration on company performance", International Journal of Quality \& Reliability Management, Vol. 19 No. 4, pp. 509-16.

Nicolau, J. and Sellers, R. (2002), “The stock market's reaction to quality certification: empirical evidence from Spain”, European Journal of Operational Research, Vol. 142, pp. 632-41. 
Ozgur, C., Meek, G. and Toker, A. (2002), "The impact of ISO certification on the levels of awareness and usage of quality tools and concepts: a survey of Turkish manufacturing companies", Quality Management Journal, Vol. 9 No. 2, pp. 57-69.

Quazi, H. and Jacobs, R. (2004), "Impact of ISO 9000 certification on training and development activities", International Journal of Quality \& Reliability Management, Vol. 21 No. 5, pp. 497-517.

Quazi, H., Hong, C. and Meng, C. (2002), "Impact of ISO 9000 certification on quality management practices: a comparative study”, Total Quality Management, Vol. 13 No. 1, pp. 53-67.

Reis, E. (1997), Estatística Multivariada Aplicada, Edições Sílabo, Lisbon.

Romano, P. (2000), "ISO 9000: what is its impact on performance?", Quality Management Journal, Vol. 7 No. 3, pp. 38-56.

Sampaio, P., Saraiva, P. and Guimarães Rodrigues, A. (2009), "ISO 9001 certification research: questions, answers and approaches", International Journal of Quality \& Reliability Management, Vol. 26 No. 1, pp. 38-58.

Sampaio, P., Saraiva, P. and Guimarães Rodrigues, A. (2010), "A classification model for prediction of certification motivations from the contents of ISO 9001 Audit Reports", Total Quality Management and Business Excellence, Vol. 21 No. 12, pp. 1279-98.

Sharma, S, (1996), Applied Multivariate Techniques, John Wiley \& Sons, New York, NY.

Siegel, S. and Castellan, J. (1988), Nonparametric Statistics for the Behavioral Sciences, McGraw-Hill, Singapore.

Singels, J., Ruel, G. and van der Water, H. (2001), "ISO 9000 series: certification and performance”, International Journal of Quality \& Reliability Management, Vol. 18 No. 1, pp. 62-75.

Sousa, R. and Voss, C. (2002), "Quality management re-visited: a reflective review and agenda for future research”, Journal of Operations Management, Vol. 20, pp. 91-109.

Tarí, J. and Molina, J. (2002), "Quality management results in ISO 9000 certified Spanish firms”, The TQM Magazine, Vol. 14 No. 4, pp. 232-9.

Tarí, J. and Sabater, V. (2004), "Quality tools and techniques: are they necessary for quality management?", International Journal of Production Economics, Vol. 92, pp. 267-80.

Terziovski, M. and Samson, D. (1999), "The link between total quality management practice and organizational performance", International Journal of Quality \& Reliability Management, Vol. 16 No. 3, pp. 226-37.

Terziovski, M., Power, D. and Sohal, A. (2003), "The longitudinal effects of the ISO 9000 certification process on business performance”, European Journal of Operational Research, Vol. 146, pp. 580-95.

Terziovski, M., Samson, D. and Dow, D. (1997), “The business value of quality management systems certification: evidence from Australia and New Zealand", Journal of Operations Management, Vol. 15, pp. 1-18.

Tsekouras, K., Dimara, E. and Skuras, D. (2002), "Adoption of a quality assurance scheme and its effect on firm performance: a study of Greek firms implementing ISO 9000”, Total Quality Management, Vol. 13 No. 6, pp. 827-41.

Wayhan, V., Kirche, E. and Khumawala, B. (2002), "ISO 9000 certification: the financial performance implications”, Total Quality Management, Vol. 13 No. 2, pp. 217-31.

Wisner, J. and Eakins, S. (1994), “A performance assessment of the US Baldrige Quality Award Winners”, International Journal of Quality \& Reliability Management, Vol. 11 No. 2, pp. 8-25. 
IJQRM

28,9

950
Withers, B. and Ebrahimpour, M. (2000), "Does ISO 9000 certification affect the dimensions of quality used for competitive advantage?", European Management Journal, Vol. 18 No. 4, pp. 431-43.

Withers, B. and Ebrahimpour, M. (2001), "Impacts of ISO 9000 registration on European firms: a case analysis", Integrating Manufacturing Systems, Vol. 12 No. 2, pp. 139-51.

Corresponding author

Paulo Sampaio can be contacted at: paulosampaio@dps.uminho.pt 